\title{
Gender Analysis of the Top Classic Papers in Otolaryngology Head and Neck Surgery
}

\author{
Beatrice Go ${ }^{1}$, Cammille Go ${ }^{2}$, Kevin Chorath ${ }^{1}$, Natasha Mirza ${ }^{1}$, Erica Thaler ${ }^{1}$, Alvaro \\ Moreira $^{3}$, and Karthik Rajasekaran ${ }^{1}$ \\ ${ }^{1}$ University of Pennsylvania \\ ${ }^{2}$ University of Pennsylvania Perelman School of Medicine \\ ${ }^{3}$ The University of Texas Health Science Center at San Antonio
}

July 27, 2021

\begin{abstract}
Objective The aim of this study is to identify and analyze the gender breakdown of first authorship contributing to the most cited papers in the field of otolaryngology, with a goal towards identifying trends in gender representation in publishing. Methods The top fifty most-cited papers were identified using Science Citation Index of the Institute for Scientific Information. Institution, journal, date of publication, research nature, and subspecialty were extracted for each article. Among the first authors, gender, h-index, percentage of first, last, and corresponding authorship positions, total publications, and citations were analyzed. Results The majority of papers were in the English language, from the United States, of clinical nature, and on otologic topics. Eighty-four percent of papers had men who were first authors although there was no difference in h-index score, authorship position, and number of publications between men and women first authors. Women first authors had significantly more citations $(\mathrm{p}=0.02)$ and average citations/year $(\mathrm{p}=0.04)$ compared to their colleagues. There was no difference in the number of articles with women first authors $(\mathrm{p}=0.17)$ or the total percentage of women authors $(\mathrm{p}=0.44)$ in papers published earlier compared to those published later. Conclusion While a promising number of women otolaryngologists are publishing high-powered articles, future initiatives to promote academic productivity and inclusivity should be considered.
\end{abstract}

\section{Hosted file}

Top 50 Manuscript_Anonymized.docx available at https://authorea.com/users/427797/articles/ 531900-gender-analysis-of-the-top-classic-papers-in-otolaryngology-head-and-neck-surgery

\section{Hosted file}

Table 1.docx available at https://authorea.com/users/427797/articles/531900-gender-analysisof-the-top-classic-papers-in-otolaryngology-head-and-neck-surgery

\section{Hosted file}

Table 2.docx available at https://authorea.com/users/427797/articles/531900-gender-analysisof-the-top-classic-papers-in-otolaryngology-head-and-neck-surgery

\section{Hosted file}

Table 3.docx available at https://authorea.com/users/427797/articles/531900-gender-analysisof-the-top-classic-papers-in-otolaryngology-head-and-neck-surgery

\section{Hosted file}


Table 4.docx available at https://authorea.com/users/427797/articles/531900-gender-analysisof-the-top-classic-papers-in-otolaryngology-head-and-neck-surgery

\section{Hosted file}

Appendix Table 1.docx available at https://authorea.com/users/427797/articles/531900-genderanalysis-of-the-top-classic-papers-in-otolaryngology-head-and-neck-surgery

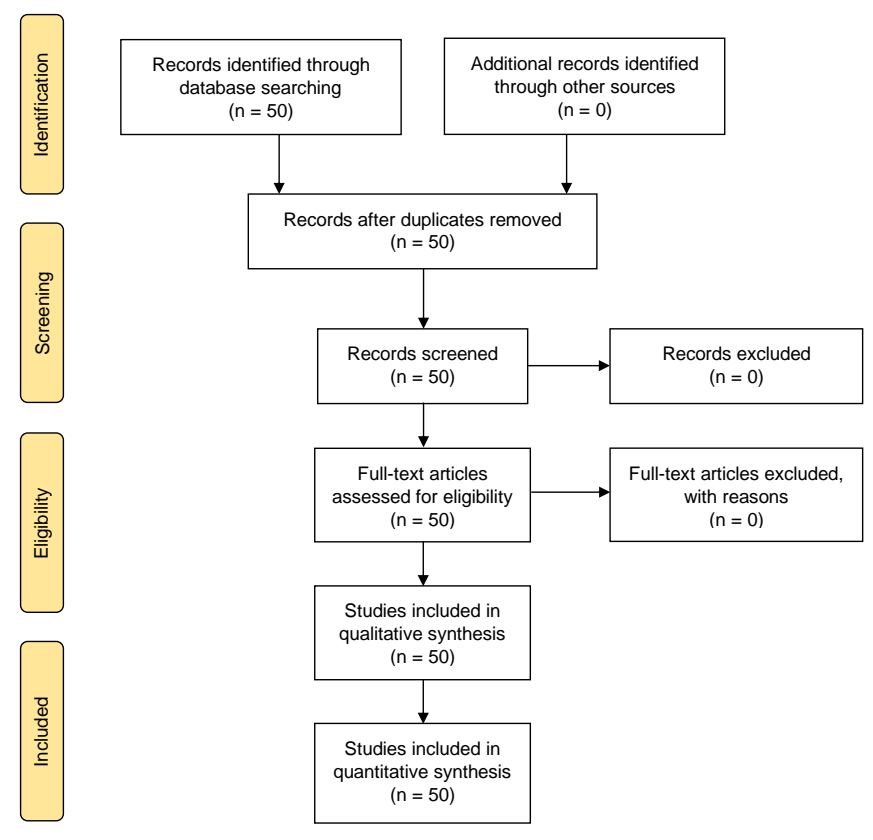

